\title{
Need analysis of the production based entrepreneurship training model: learning entrepreneurship in higher education
}

\author{
Ganefri $^{1}$, Hendra Hidayat ${ }^{2 *}$, Asmar Yulastri ${ }^{1}$, Ifdil Ifdil ${ }^{1}$ \\ ${ }^{1}$ Universitas Negeri Padang, Indonesia, \\ ${ }^{2}$ Universitas Bung Hatta, Indonesia, \\ ${ }^{*}$ Corresponding author, ఏe-mail: hendrahidayatmpd@gmail.com
}

\begin{abstract}
The purpose of this study is to describe the needs analysis of production-based entrepreneurship training models in higher education. This is a quantitative and descriptive research with data purposively collected from 110 students that took entrepreneurship courses using questionnaires. The obtained data analyzed using the descriptive statistics method. Furthermore, this research was limited to the definition stage, which is to obtain information on the analysis of production-based entrepreneurship training needs seen from entrepreneurship learning. The results showed that the need for production-based on entrepreneurship training was categorized at a fairly good level, which contained elements of learning and teaching. Needs analysis is an important research activity used to obtain indepth information as a basis for carrying out subsequent activities.
\end{abstract}

Keywords: Needs analysis, entrepreneurship training, production based.

How to Cite: Ganefri, G., Hidayat, H., Yulastri, A., \& Ifdil, I. (2020). Need analysis of the production based entrepreneurship training model: learning entrepreneurship in higher education. COUNS-EDU: The International Journal of Counseling and Education, 5(2), 58-63. DOI: $10.23916 / 0020200528530$

\section{Introduction}

Currently, there is a global increase in economic development with tremendous growth in trade and property, thereby impacting on the socio-economic life of various countries, including Indonesia (Antoni, Akmal, \& Muslim, 2019; Antoni, Yuliviona, Kamela, \& Muslim, 2020). According to Livingstone (2018), higher education which is properly developing in Indonesia is one of the driving forces for a nation's economy. However, there is still a gap in society's job market, thereby leading to high unemployment rates for higher education graduates. One of the advantages of higher education is its ability to provide skilled and professional workers needed by the job market. According to Mondragón-Vélez, Peña, Wills, and Kugler (2010) the demand in the labor market is very high, and the availability of quality resources in Indonesia allow for economic change and a better welfare level. Based on 2017 data obtained in a research carried out by Kemenristekdikti (2017), there are a total of 4,504 campuses in Indonesia. With these numerous campuses in Indonesia, graduates are expected to bring tremendous economic changes to the country's economy. Unfortunately, in reality, the economic conditions and the nation's welfare do not change significantly due to the number of unemployed college graduates.

Learning in higher education needs to be properly synchronized with society's development and the various demands of the job market. Currently, higher education graduates are less able to implement their knowledge in their professional field with low morale. Therefore, higher institutions need to ensure that 
their educational curriculums are in line with the world of work, while graduates can create employment opportunities, rather than looking for jobs. In the last five years, the government, through the ministry of research and higher education, which is currently the ministry of education and culture, is actively and focused on offering various programs to improve students' soft skills. Some of these programs are scientific reasoning that strengthens students' hard and soft skills. Furthermore, campuses also have course programs to develop students' soft skills, such as entrepreneurship. The government also facilitates students by providing business funding assistance, on a national basis through creative and entrepreneurship programs. Essentially learning in higher education prepares graduates that have competences in their respective fields of knowledge and are also provided with entrepreneurial, technological, and social competences.

Entrepreneurship learning is designed for higher education graduates to survive and compete in the job market (Taatila, 2010) in accordance with the current digitalization era and the complexity of the nation's economic problems. Besides that, it is carried out to shape students' competence and entrepreneurial character. High morale, courage, interpersonal communication, teamwork, and discipline are some of the characteristics of entrepreneurship that are indispensable to today's higher education graduates. Similarly, marketing skills, scientific products (Antoni et al., 2019), reading market opportunities, creativity, and business innovation are some of the entrepreneurial competencies that need to be understood and implemented for students and graduates of higher education in Indonesia.

The materials used in higher education are not in line with the field practice because students are less enthusiastic, with the inability of the study plans to predict, understand and develop their selfpotential, work ethics, responsibility, optimal communication and evaluation. Furthermore, learning entrepreneurship can become dull when students only listen to monotonous lectures and stories from the teacher, without competence and understanding of entrepreneurial character, because graduates prefer to look for jobs rather than open employment opportunities. Good entrepreneurship learning tends to positively impact on their readiness to open employment opportunities, thereby leading to a yearly decrease in the unemployment rate. Figure 1 is the latest data released by the Indonesian Central Bureau of Statistics.

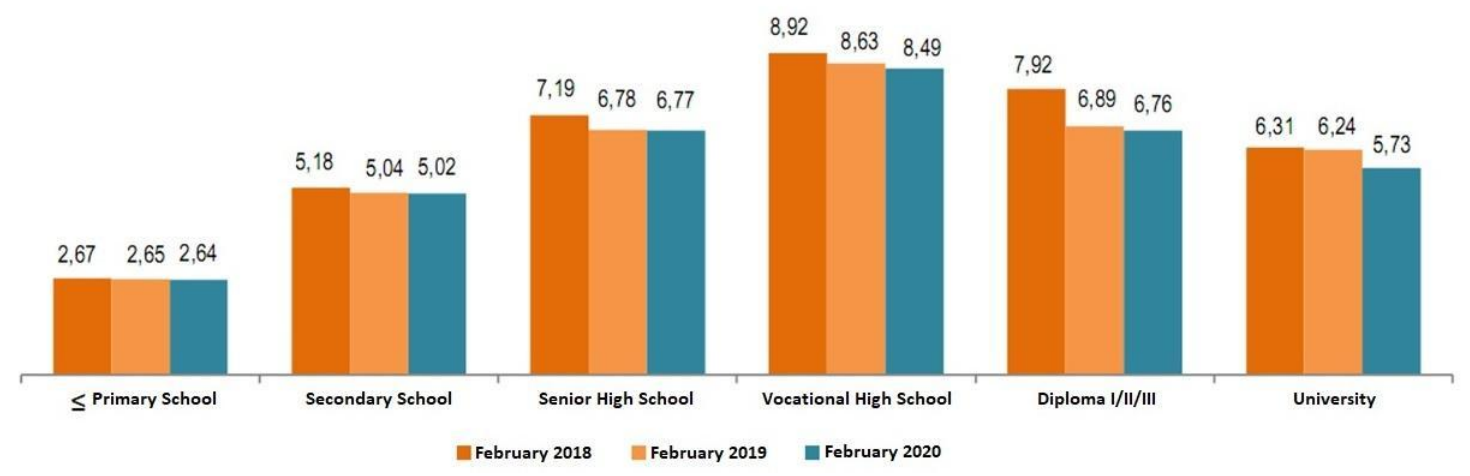

Figure 1. Open Unemployment Rate in Indonesia from February 2018-February 2020 Source: Central Statistics Agency, May 2020

Based on the Central Statistics Agency, unemployment has increased by 60 thousand people in the past years, with a decrease in the open unemployment rate to $4.9 \%$ in February 2020 (BPS, 2020). However, this condition does not include the negative impact caused by the outbreak of the Covid-19 pandemic. However, the National Development Planning Agency (Bappenas) predicts that due the pandemic, the unemployment rate in 2021 is likely to increase to 12.7 million people. In 2020 it is estimated that approximately 8.1 million people or $9.2 \%$ are going to be influenced by the open unemployment rate (TPT) (Thomas, 2020). Therefore, it is essential for higher education to immediately enhance entrepreneurship learning by providing alternative solutions through production-based entrepreneurship training models to students to enable them to compete in this globalization era. Entrepreneurship education and training is a process of facilitating individuals with concepts and skills to be able to recognize business opportunities and have insight, confidence, and ability to act (McIntyre, 2000). One of the training activities used to help develop active, creative entrepreneurial learning and training for students competence and character are through production-based training. This allows them to 
produce various goods and services following the conditions of the curriculum set and according to the market and society's needs. Therefore, this study aims to describe the analysis of the needs of productionbased on entrepreneurship training models in higher education.

\section{Method}

This study utilized the development research (Gall \& Gall, 2003), with a quantitative descriptive approach used to examine the analysis of production-based entrepreneurship training needs in higher education. Furthermore, this research is limited to the definition stage, which is to obtain information on the analysis of production-based entrepreneurship training needs from higher education. Data were purposively collected from 110 students that took entrepreneurship courses at Bung Hatta University, Padang, Indonesia, using a questionnaire. The study was also carried out using a 4-stage model development. According to Akbar \& Hartono (2017), the research and development stages were carried out with four stages of development, namely 1) Definition, 2) Design, 3) Development and 4) Distribution.

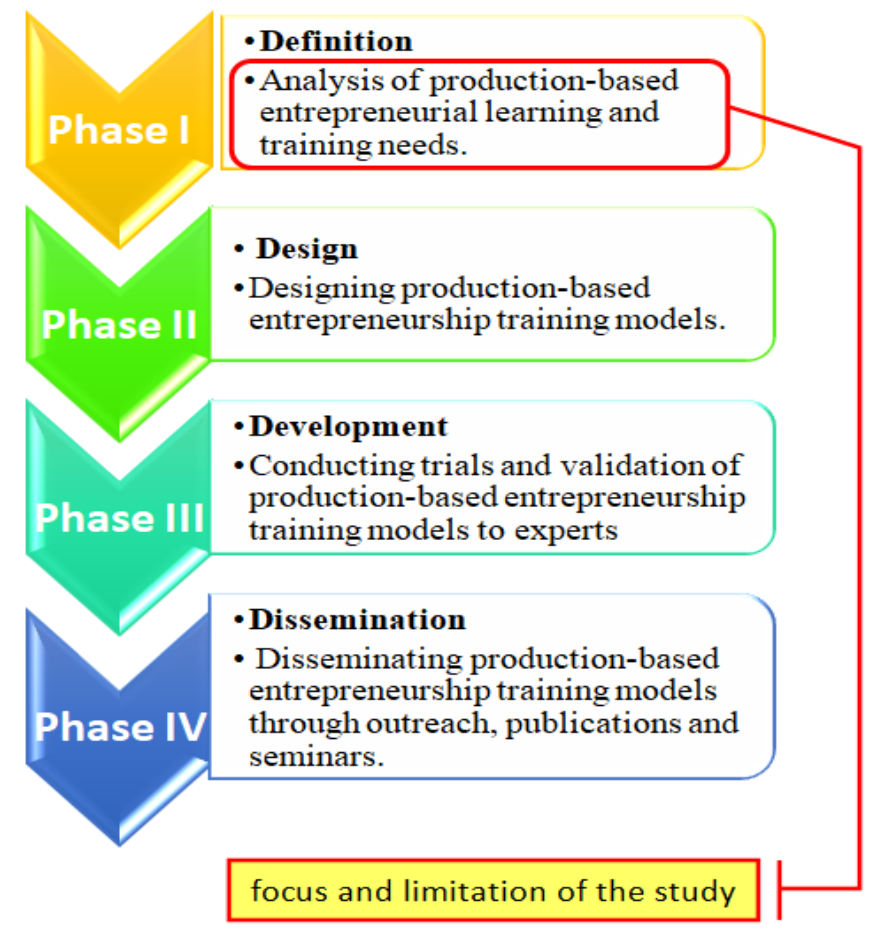

Figure 2: The framework for the research stages of the production-based entrepreneurship training model.

This needs analysis stage involves distributing questionnaires during the learning process and analyzing data using descriptive statistics. Several items were asked to students regarding 1) learning tools, 2) understanding and developing self-potential, 3) work ethics, responsibility, and pride, 4) learning implementation and planning, 5) knowing student character, 6) learning activities that we are educating, 7) communication with students, and 8) evaluation. In this process, students were asked to fill a questionnaire using the yes or no answer options. This means that from this questionnaire, information used to design and develop a training model production-based entrepreneurship model is obtained.

\section{Results and Discussions}

This study was implementation based on the four stages of the research, which starts with a needs analysis. In addition, it aims to determine and obtain information on entrepreneurship learning in forming a training model using the right analysis (Hidayat, Ardi, Yuliana, \& Herawati, 2019; Hidayat, Tamin, Herawati, Khairul, \& Syahmaidi, 2019). Production-based entrepreneurship training is generally similar to entrepreneurship learning. The only difference is that in production-based training, students are actively 
involved and have a target of products to produce for commercial purposes, which are in line with each department's field and following market needs. According to Hidayat (2015), production-based learning provides students with the opportunity to develop thinking skills in higher education. The results of the needs analysis can be seen in Figure 3:
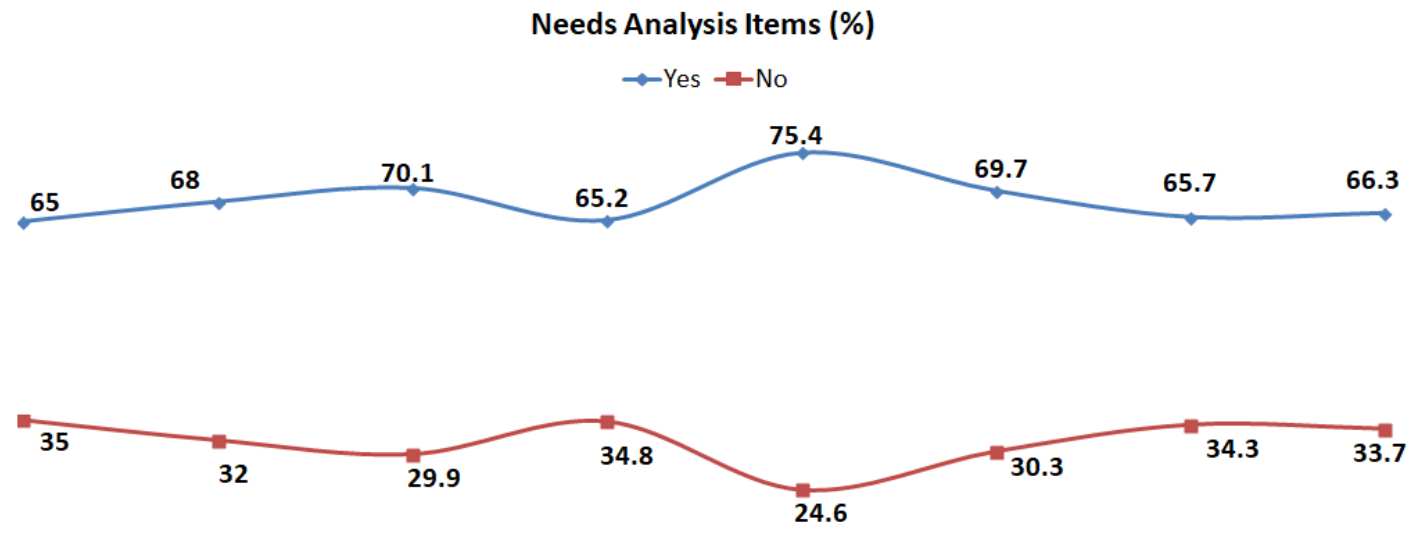

\begin{tabular}{|c|c|c|c|c|c|c|c|}
\hline Learning Media & $\begin{array}{c}\text { Understand and } \\
\text { Develop Self } \\
\text { Potential }\end{array}$ & $\begin{array}{c}\text { Work Ethic, } \\
\text { Responsibility and } \\
\text { Pride }\end{array}$ & $\begin{array}{l}\text { Implementation } \\
\text { and Learning } \\
\text { Planning }\end{array}$ & $\begin{array}{l}\text { Know the } \\
\text { character of } \\
\text { students }\end{array}$ & $\begin{array}{c}\text { Educational } \\
\text { Learning Activities }\end{array}$ & $\begin{array}{l}\text { Communication } \\
\text { with students }\end{array}$ & Evaluation \\
\hline
\end{tabular}

Figure 3. Graph of item analysis of entrepreneurial learning needs.

Data from the questionnaire filled in by students were descriptively analyzed to obtain an overview of the need for production-based entrepreneurship training. The need for an achievement response analysis of 8 (eight) aspects distributed to students taking entrepreneurship courses showed that an average of $68.18 \%$ and $31.83 \%$ of the students, provided Yes and No answers. The $31.83 \%$ of students that answered "No" indicates that they do not understand the importance of aspects of entrepreneurship learning. The item of analysis of needs in the highest category of $75.4 \%$ is student character, therefore, educators' need to pay adequate attention and consideration, to this aspect of entrepreneurship learning (Syam, Akib, Yunus, \& Hasbiah, 2018). Meanwhile, the lowest score category is the learning device aspect with a value of $65 \%$, is an integral part, and in accordance with Ganefri et al. (2018) research, which stated that it is a scenario and storyline for students and educators. The low-value category of the acquisition of filling out this questionnaire on the aspect of learning tools assumes that students do not understand the principles and essence of the importance of learning tools.

Furthermore, information was obtained in designing a draft production-based entrepreneurship training model using the needs analysis results, which found that entrepreneurship learning was at a reasonably good level. According to Lüthje \& Franke (2003), entrepreneurship education and training aim to inspire students to arouse emotions and change mindsets. It also fosters entrepreneurship as a new mindset, and part of entrepreneurial education competencies (Edwards-Schachter, García-Granero, Sánchez-Barrioluengo, Quesada-Pineda, \& Amara, 2015) (Karimi, Biemans, Lans, Aazami, \& Mulder, 2016), based on learning experiences and training activities (Kakouris, 2017; Robinson et al., 2016). The study shows the importance of learning devices, especially in entrepreneurship (Ganefri et al., 2018; Hidayat, 2017a, 2017b), and in understanding as well as developing students' self-potential, such as ethics, character and a sense of responsibility learning (Hidayat, 2017; Hidayat, Yulastri, Sriwahyuni, \& Zoni, 2018) (Hidayat, Ardi, et al., 2019; Hidayat, Herawati, Hidayati, \& Syahmaidi, 2018; Hidayat, Herawati, Tamin, \& Syahmaidi, 2018; Kusumaningrum, Ganefri, \& Hidayat, 2015; Yulastri \& Hidayat, 2017). This indicates that entrepreneurship learning considers need analysis, as well as the objectives, learning tools and characters integrated into the education. 


\section{Conclusions}

In conclusion, the production-based entrepreneurship training model needs to be implemented in learning for all areas of expertise. Therefore, in order to design this entrepreneurial training model following the learning principles, it is necessary to have an initial study in the form of a needs analysis. The research data used in this study showed an average of $68.18 \%$ and $31.83 \%$ yes and no answers. Needs analysis is a critical research activity used to obtain in-depth information as material for subsequent activities. Production-based entrepreneurship training activities are an alternative in shaping entrepreneurship learning that allows students to develop thoughts, skills, and cooperation.

\section{Acknowledgements}

The authors are grateful to all those that supported and cooperated with them throughout this research process. Furthermore, the authors are also grateful to DRPM Dikti for funding this 2020 research.

\section{References}

Akbar, F. I., \& Hartono, R. (2017). Pengembangan Lembar Kegiatan Peserta Didik Dengan Model Pengembangan 4-D Pada Materi Mitigasi Bencana dan Adaptasi Bencana Kelas X SMA. Jurnal Pendidikan Geografi: Kajian, Teori, dan Praktek dalam Bidang Pendidikan dan Ilmu Geografi, 22(2), 134145.

Antoni, A., Akmal, A., \& Muslim, I. (2019). Long-Term Relationships of Macroeconomic Variables on Indonesian Foreign Exchange Reserves. Jurnal Menara Ekonomi: Penelitian dan Kajian Ilmiah Bidang Ekonomi, 5(2).

Antoni, A., Yuliviona, R., Kamela, I., \& Muslim, I. (2020). The Effect of Marketing Mix on Tourist Decision in Mandeh Island West Sumatra, Indonesia. Jurnal Menara Ekonomi: Penelitian dan Kajian Ilmiah Bidang Ekonomi, 6(1).

BPS. (2020). BeritaResmiStatistik: KeadaanKetenagakerjaan Indonesia Februari 2020. No. 40/05/Th. XXIII, 05 Mei 2020.

Edwards-Schachter, M., García-Granero, A., Sánchez-Barrioluengo, M., Quesada-Pineda, H., \& Amara, N. (2015). Disentangling competences: Interrelationships on creativity, innovation and entrepreneurship. Thinking skills and creativity, 16, 27-39.

Gall, J. P., \& Gall, M. D. (2003). Instructor's manual to accompany Educational research: An introduction, by Gall, Borg, and Gall: Pearson Education.

Ganefri, G., Hidayat, H., Yulastri, A., Mardin, A., Sriwahyuni, D., \& Zoni, A. A. (2018). Perangkat Pembelajaran Pedagogi Entrepreneurship Dengan Pendekatan Pembelajaran Berbasis Produk di Pendidikan Vokasi. Paper presented at the Prosiding Seminar Nasional \& Internasional.

Hidayat, H. (2015). Production based Learning: An Instructional Design Model in the context of vocational education and training (VET). Procedia-Social and Behavioral Sciences, 204, 206-211.

Hidayat, H. (2017a). How is the Application and Design of a Product-Based Entrepreneurship Learning Tools in Vocational Higher Education? Paper presented at the International Conference on Technology and Vocational Teachers (ICTVT 2017).

Hidayat, H. (2017b). How to Implement Technology Science for Entrepreneurship by Using ProductBased Learning Approach and Participatory Action Learning System in Higher Education? Advanced Science Letters, 23(11), 10918-10921.

Hidayat, H., Ardi, Z., Yuliana, \& Herawati, S. (2019). Exploration of the need analysis for technopreneurship scientific learning models in higher vocational education. International Journal of Economics and Business Research, 18(3), 356-368.

Hidayat, H., Herawati, S., Hidayati, A., \& Syahmaidi, E. (2018). Pembelajaran Kewirausahaan dengan pendekatan berbasis produksi sebagai alternatif mempersiapkan lulusan berkualitas di pendidikan tinggi. Paper presented at the Prosiding Seminar Nasional Pakar.

Hidayat, H., Herawati, S., Tamin, B. Y., \& Syahmaidi, E. (2018). How is the practicality of technopreneurship Scientific learning model design in vocational higher education? International Journal of Scientific Research and Management, 6(09). 
Hidayat, H., Tamin, B. Y., Herawati, S., Khairul, K., \& Syahmaidi, E. (2019). The contribution of technopreneurship scientific learning and learning readiness towards the entrepreneurship learning outcomes in higher vocational education. Jurnal Pendidikan Vokasi, 9(1), 21-32.

Hidayat, H., Yulastri, A., Sriwahyuni, D., \& Zoni, A. A. (2018). Contribution of Entrepreneurship Pedagogy Learning Model with Production-Based Learning Approach to Entrepreneurs Learning Outcomes in Vocational Higher Education. International Journal of Scientific Research and Management, $6(10)$.

Kakouris, A. (2017). Constructivist entrepreneurial teaching: The TeleCC online approach in Greece Entrepreneurship Education: Emerald Publishing Limited.

Karimi, S., Biemans, H. J., Lans, T., Aazami, M., \& Mulder, M. (2016). Fostering students' competence in identifying business opportunities in entrepreneurship education. Innovations in education and teaching international, 53(2), 215-229.

Kemenristekdikti. (2017). Berapa Jumlah Perguruan Tinggi di Indonesia? Jakarta: forlapdikti.

Kusumaningrum, I., Ganefri, G., \& Hidayat, H. (2015). Improving Students' Entrepreneurial Interest using Production Based Learning Model in TVET. Paper presented at the 3rd UPI International Conference on Technical and Vocational Education and Training.

Livingstone, D. W. (2018). The education-jobs gap: Underemployment or economic democracy. Canada: University of Toronto press.

Lüthje, C., \& Franke, N. (2003). The 'making' of an entrepreneur: testing a model of entrepreneurial intent among engineering students at MIT. R\&d Management, 33(2), 135-147.

McIntyre, J. R. (2000). University education for entrepreneurs in the United States: a critical and retropspective [sic] analysis of trends in the 1990's: Georgia Tech Center for International Business Education and Research ....

Mondragón-Vélez, C., Peña, X., Wills, D., \& Kugler, A. (2010). Labor market rigidities and informality in colombia [with comment]. Economía, 11(1), 65-101.

Robinson, S., Neergaard, H., Tanggaard, L., Krueger, N., McCracken, M., \& Matlay, H. (2016). New horizons in entrepreneurship: from teacher-led to student-centered learning. Education + training.

Syam, A., Akib, H., Yunus, M., \& Hasbiah, S. (2018). Determinants of entrepreneurship motivation for students at educational institution and education personnel in Indonesia. Journal of Entrepreneurship Education, 21(2), 1-12.

Taatila, V. P. (2010). Learning entrepreneurship in higher education. Education+ training.

Thomas, V. F. (2020). Angka Pengangguran 2020 Terburuk, Apa yang Bisa dilakukan Jokowi? Retrieved 16 September 2020, 2020, from https://tirto.id/angka-pengangguran-2020-terburuk-apa-yang-bisadilakukan-jokowi-fKQg

Yulastri, A., \& Hidayat, H. (2017). Developing an Entrepreneurship Module by Using Product-Based Learning Approach in Vocational Education. International Journal of Environmental and Science Education, 12(5), 1097-1109. 